\title{
Supply Chain Management Dimensions, Supply Chain Performance and Organizational Performance: An Integrated Framework
}

\author{
Anant Deshpande \\ Center for Distance Learning, State University of New York Empire State College \\ 113 West Avenue, Saratoga Springs, NY, USA 12866 \\ Tel: 1-956-750-0079Ｅ-mail: Anant.Deshpande@esc.edu
}

Received: January 3, 2012

Accepted: February 7, $2012 \quad$ Published: April 16, 2012

doi:10.5539/ijbm.v7n8p2

URL: http://dx.doi.org/10.5539/ijbm.v7n8p2

\begin{abstract}
Evidence has shown that organizations seldom achieve the competitive advantage offered by supply chain management technique. This may be attributed to the fact that current methodologies for analyzing supply chains are not sufficiently comprehensive, particularly when it comes to understanding the complexities of SCM and organization performance in an unified context. In addition, researchers have not comprehensively answered key questions such as what are the linkages between different dimensions of SCM and what are the linkages between the underlying dimensions of SCM and SCM performance. Gap also exists in terms of understanding of the relationship between SCM performance measures and organizational performance measures. The study seeks to address these issues. Based on a comprehensive literature review, a theoretical framework and propositions are derived. In culmination, the description for possible findings and implications of the study for managers is considered. Overall, we argue that increased interaction between important constituents of supply chain management will enhance the organization's ability to meet desired goals. Finally, directions for future research are also presented.
\end{abstract}

Keywords: Supply Chain Management, Supply chain performance, Organizational performance

\section{Introduction}

Despite the increasing amount of attention paid to Supply chain management (SCM) practices by practitioners and academicians (Donlon, 1996; Malik, Niemeyer \& Ruwadi, 2011; Tracey, Lim \& Vonderembse, 2005) failures in effectively implementing SCM practices still exist (Handfield, Krause, Scannel \& Monczka, 2000; Handfield \& Nichols, 1998; Moberg, Speh, \& Freese, 2003). One of the main reasons for the failure to successfully implement SCM can be attributed to the fact that there is lack of agreement between researchers as to what constitutes the critical dimensions of SCM (Chen \& Paulraj, 2004a, 2004b; Donlon, 1996; Lambert, Dastugue, \& Croxton, 2005; Li, B.Nathan, R.Nathan \& Rao, 2005; Min \& Mentzer, 2004; Tan, Lyman \& Wisner 2002). Secondly, studies at some point in their analysis clearly mention the need to interlink the SCM dimensions and the firm performance (Donlon 1996; Lambert, Chen \& Paulraj, 2004a, 2004b; Li, B.Nathan, R.Nathan \& Rao, 2005; Tan et al., 2002). Researchers have typically not addressed this issue. Third, supply chain is complex entity which consists of various echelons, for instance, suppliers, manufacturers, distributors and consumers (Beamon, 1999). Challenges exist in terms of identifying appropriate performance measures for the analysis of supply chain (Arzu Akyuz, \& Erman Erkan, 2010; Beamon, 1999). Researchers have thus far been content in limiting their choice of performance measures. For instance, Cohen and Lee (1988) consider cost as an important measure of supply chain management performance. Customer responsiveness has also been recognized as an important dimension of SCM performance (Christy \& Grout, 1994). In addition, Lee and Bullington (1993) identify supply chain flexibility as an important measure of SCM performance. Studies have generally ignored the complexity in levels of supply chain and fail to completely characterize the supply chain system (Beamon, 1999). In order to capture the construct of performance measure, all the different dimensions of SCM performance need to be considered simultaneously. In addition, it is recognized that since SCM has firm level implications and it becomes imperative to measure effects of SCM performance on organizational performance measures (Green, McGaughey \& Casey, 2006). Furthermore the question about which dimensions of SCM are distinctly related to supply chain performance and finally to firm performance has largely gone unnoticed (Ansoff \& Sullivan, 1993; Bechtel \& Jayaram, 1997; Chopra \& Meindl, 2001; Harrison \& Hoeck, 
2002; Mentzer, Dewitt, Keebler, Min, Nix \& Smith, 2001; Mentzer, Min \& Zacharia, 2004).

Based on the above discussions this study seeks to investigate the following research questions:

- What are the underlying critical dimensions of SCM?

- What specific dimensions of SCM are directly related amongst each other and to SCM performance measures?

- What specific dimensions of SCM performance are directly related amongst each other and to organizational performance measures?

\section{Motivation and Contributions of the study}

The study is of paramount importance to academicians and practitioners as the proposed framework is expected to uncover many neglected relationships that are of interest to managers. In addition, specific patterns of SCM practices would also be revealed which would further encourage managers to implement this technique and possibly improve both SCM and organization performance. The study offers three major contributions. First on a macro level the uniqueness of the study lies in the fact that no study to date has examined the interrelationships between critical SCM dimensions, supply chain performance and organization performance in a unified context. The study seeks to systematically address this issue. Second on a micro level the study seeks to uncover many potentially neglected areas in SCM literature. The study can also be seen as an answer to the call for research seeking more investigation into the relationship of strategic purchasing with supply management concepts (Chen \& Paulraj, 2004a; Cousins, 2005; Dyer \& Singh, 1988). In addition, as observed by Styles and Amber (2000), there is a need to study the linkage between supply chain relationships and supply chain performance. This study is in line with this call for such added investigation. The proposed theoretical framework will also address the gap in the literature in terms of consideration of more than one performance measure. For instance, as mentioned by Beamon (1999), flaws existed with supply chain models using only one supply chain performance measure. Various supply chain performance measures identified in the literature include: cost, time and flexibility (Neely, Gregory \& Platts, 1995). Models using a single performance measure can indicate a lack of attention to other performance measures (Beamon, 1999). As mentioned by V. Kumar, U. Fantazy, Kumar and Boyle (2006) there has been a lack of studies demonstrating the relationship between supply chain flexibility and business performance of organizations. This study can be seen as a step taken to investigate this critical issue. In addition, as mentioned by Vickery, Calantone, and Droge (1999), there is a need to study existing relationships between the different dimensions of supply chain management performance. This is important because one performance dimension may be connected with other performance dimensions and managers can get a better perspective on interdependent performance dimensions and thereby improve overall performance. Third there has been lack of studies investigating the linkage between specific SCM practices and SCM performance (Lockamy III \& McCormack, 2004). The integrated framework developed in the current study will address this issue. In addition, the current study incorporates the dimension of customer responsiveness time as a dimension in the supply chain performance construct. There has been a call for introduction of this dimension by researchers (Beamon, 1999; Gunasekeran, Patel \& Tirtiroglu, 2001; Lee \& Bullington, 1992). Models in the past have only explored limited dimensions of supply chain performance such as cost (Pyke \& Cohen, 1994), and flexibility (Sanchez \& Perez, 2005). There is a need to incorporate the customer-oriented performance measure into this evaluation considering the importance of customer satisfaction in supply chain management strategy (Williams \& Visser, 2002).

\section{Literature Review}

\subsection{Identification of supply chain management dimensions and brief description}

In order to achieve a competitive advantage, supply chains need to be managed appropriately (Bode, Wagner, Petersen \& Ellram, 2011; Francois \& Gilles, 2005; Salvador, Forza, Rungtusanatham \& Choi, 2001; Scannel, Vickery \& Droge, 2000). The set of practices developed by an organization to effectively manage the functioning of a supply chain are known as supply chain management practices (Li, Nathan,B., Nathan,T., \& Rao, 2006). An extensive literature review was carried out to identify different dimensions of the supply chain management practices. The rationale used in the study followed the selection of supply chain management practices which cover both the upstream and downstream sides of the supply chain (Celtek \& Kaynak, 1999; Li et al., 2005). Table 1A and Table 1B present some of the studies and commonly identified dimensions under supply chain management. 
From Table 1A and Table 1B, it can be said that the literature is divided in terms of selection of different dimensions for the use in supply chain management practices. Some of the reasons for this gap, mentioned in different studies, include the increase in length of a survey and the complexity of a measurement instrument if all the practices were included (Chen \& Paulraj, 2004a; S.Li et al., 2005; Min \& Mentzer, 2004). In order to capture the holistic perspective of supply chain management, an extensive analysis of different SCM practices is required.

From the literature review mentioned in Table 1A and 1B and the above-mentioned rationale, three important supply chain management dimensions were identified. These dimensions include long term relationships, concurrent engineering and strategic purchasing. All the above-mentioned dimensions selected from the literature attempt to explore the supply chain management construct in a holistic manner rather than being limited only to certain practices covering one particular aspect of the SCM domain. A brief introduction of each of the three SCM dimensions is presented next.

\subsubsection{Long term relationships}

The central tenet of long term relationships is the ability to maintain a cooperative relationship between two or more entities in lieu of mutual economic gains (Krause, Handfield \& Tyler, 2007). Organizations engaged in SCM should constantly monitor the long term relationships dimension of the supply chain. Some of the key advantages of maintaining long-term relationships include ease of important information sharing between involved partners, sharing a certain level of trust and improvements in knowledge management and overall firm level benefits (Griffith, Harvey \& Lusch, 2006).

\subsubsection{Concurrent engineering}

Concurrent engineering deals with the early involvement of suppliers, customers, and buyers during the product/service design stage (Celtek \& Kaynak, 1999). Concurrent engineering also involves simultaneous working together of different member constituents. This is important in supply chain context. For instance, the importance of the involvement of customers during the early stages is stressed in many studies (Divett, Crittenden \& Henderson, 2003; Li et al., 2005; Li et al., 2006; Tan et al., 2002; Uncles, Dowling, \& Hammond, 2003; Vickery, Jayaram, Droge, \& Calantone, 2003). The critical element in concurrent engineering practice is the simultaneous inclusion of all phases of the related divisions (Jarvis, 1999). This essentially means that during the product design stage, the customers who are part of the concurrent engineering crossfunctional teams can voice their opinions along with other functional area members such as marketing, production, and finance and help in reduction of lead time.

\subsubsection{Strategic purchasing}

Purchasing has been viewed as an essential component of a firm's strategic planning process (Castaldi, Ten Kate, \& Den Braber, 2011; Cousins, 2005; Wade, Hartley, Turner \& Pierce, 1996). As recognized by Carr and Peterson (2002), strategic purchasing is an upstream component of supply chain management (SCM). This dimension involves strategically selecting the suppliers. The construct of strategic purchasing is operationalized in terms of dimensions such as whether purchasing is aligned with the firm's strategic orientation, whether purchasing is carried out while keeping the long-term issues of the firm in mind, and whether the suppliers have adequate knowledge of the firm's strategic goals (Chen \& Paulraj, 2004a, 2004b). Purchasing is often linked to an organization's achieving competitive advantage (Wade et al., 1996).

\subsection{Supply Chain Management Performance}

The major challenge faced by researchers in Supply Chain (SC) literature is to analyze the SC system's performance (Arzu Akyuz, \& Erman Erkan, 2010; Beamon, 1999). Often vague terms, such as "adequate" or "inadequate" are commonly used to quantify performance measures (Beamon, 1999). The analysis of supply chain performance becomes complex because of different entities involved such as suppliers, manufacturers, wholesalers, and customers. For the purpose of this study, supply chain management performance is defined as the multiple measures of performance developed by the organization to gauge the ability of a supply chain to meet an organization's long-term and short-term objectives. Table 2 represents results of the literature review. Based on the literature review, three major SCM performance measures such as SC delivery flexibility, inventory cost, and customer responsiveness time were identified. A brief description of each of the dimension of SC performance is presented next.

\section{Insert Table 2 -here}

The measurement of SC delivery flexibility is essential to estimate the responsiveness of a supply chain. Delivery flexibility deals with delivering products which are desired by the customer to the market as quickly as 
possible. The higher the flexibility, the better is the responsiveness of a supply chain. For instance, if the supply chain is highly flexible, it would continually meet the changing needs of customers and help customers to view the supply chain favorably (Beamon, 1999; Gunasekaran et al., 2001). The construct of delivery flexibility is operationalized in terms of ability of supply chain to change or deliver orders according to fluctuations in demands of customers (Das \& Abdel-Malek, 2003; Neely et al., 1995; Sanchez \& Perez, 2005; V. Kumar., Fantazy, U. Kumar \& Boyle, 2006)

From a supply chain perspective, inventory levels should be optimized because maintenance of inventory is expensive and poses problems (Piplani \& Fu, 2005; Stewart, 1995). The inventory cost measure involves inventory costs associated with scrap and rework of inventory, and is operationalized in terms of costs of held up finished goods in transit. In addition, the construct is also operationalized in terms of the cost associated with management of inventory in stocks, and loss of sales due to shortage of inventory accounting for lost sales/lost production (Agarwal \& Shanker, 2002; Gunasekeran et al., 2002).

Customer responsiveness time is an important measure of performance of the supply chain as it involves the delivery time and the order placement time. This dimension is operationalized in terms of ability of the supply chain to respond to changes in customer demand and meet timely orders (Beamon, 1999; Edget \& Snow, 1997; Uncles, Dowling, \& Hammond, 2003).

\subsection{Organization Performance Measures}

Organizations implementing SCM have obtained improved performance. Cost savings, increased revenues, and the reduction of defects in products are some of the chief advantages of introducing supply chain management (Shin, Collier \& Wilson, 2000). It has been demonstrated that business profitability is closely associated with market and business shares (Buzzel, Gale \& Sultan, 1975). Based on the long- term and short-term goals of the $\mathrm{SCM}$, the organizational performance measures identified were and financial and market performance and customer satisfaction. In context of SCM, the financial and market performance is operationalized in terms of market share, return of total assets, annuals sales growth (Tan et al., 1999; Venkatraman \& Ramanujan, 1987). The customer satisfaction dimension is measured by total product value to the customer; meeting quality standards set by the customer, understanding customer needs, retention of loyal customers and alignment of organizations goal in terms of customer needs (Feciková, 2004; Jamal \& Naser, 2002).

\section{The Integrated Framework and the Propositions}

This section of the paper proposes the integrated framework. For the purpose of developing relationships, in addition to the strategic management literature, operations management literature, marketing literature, and technology literature were also considered. This approach was used to provide a detailed analysis of the research questions to be proposed. Figure 1 represents the integrated framework indicating the interrelationships between SCM dimensions, SCM performance and organization performance. The following subsections explore the previously mentioned interrelationships in greater detail. The integrated framework provides managers with a overarching framework for linkages between SCM dimensions, SCM performance, and organization performance.

\section{Insert Figure 1 -here}

\subsection{Strategic Purchasing and Long- term Relationships}

The benefits of strategic purchasing involve the formation of effective communication channels and developing a long-term strategic orientation with the supply network for achieving mutual goals (Carr \& Pearson, 2002; Harland, Lamming \& Cousins, 1999). The role of purchasing evolved over the years as firms started recognizing the importance of aligning long-term organizational goals with that of suppliers and effectively communicating strategic goals to all components of the supply chain. Strategic purchasing involves the formation of a flexible supply base (Giunipero \& Eltantawy, 2004); this helps enhance long term relationships. Communicating a fixed strategy and exclusively involving the suppliers who meet the strategic requirements of the firm improves communication and understanding between members of the supply chain, thereby assisting in cultivation of mutually beneficial long term relationships (Olkkonen, Tikkanen \& Alajoutsijärvi, 2000). Accordingly we posit:

Proposition 1a. Strategic purchasing has a positive impact on long term relationships.

\subsection{Strategic Purchasing and Concurrent Engineering}

One of the important aspects of strategic purchasing involves selecting specific suppliers and maintaining effective interactions between suppliers and buyers (Campbell, 1985; Cunningham, 1982). Interaction and communication between different component members at an early stage in product development have been 
deemed important for the success of concurrent engineering practices (Bradley, 1995; Holmes, 1994; Koufteros et al., 2001; Sharifi \& Pawar, 2002). In addition, since the chief emphasis is on improving quality, it is beneficial to select specific suppliers who meet the quality requirements of the organization. If suppliers have adequate knowledge of a firm's strategic orientation, they can contribute to the cross-functional teams by effectively sharing information (Fergusion, Hartley, Turner \& Pierce, 1996). This would lead to further improved cross-functional team performance in a concurrent engineering context and consequently, the concurrent engineering performance. The above arguments lead us to the following proposition.

Proposition $1 \mathrm{~b}$. Strategic purchasing has a positive impact on concurrent engineering.

\subsection{Strategic Purchasing and Reduced Inventory Cost}

As mentioned by Carr and Pearson (2002), strategic purchasing offers the firm options to meet the quality levels, reduction in inventory costs and cycle times. A study by Tracy, Leng, Vondersembse and Bardi (1995) revealed a significant difference in terms of inventory stocks management between firms utilizing strategic and non-strategic purchasing in Just-in-Time (JIT) environments. Increased communication between members of the purchasing and warehouse departments helps in optimizing the levels of inventory. This further helps in the reduction of costs as members of the purchasing unit can effectively communicate the need to the supplier and the delivery can be synchronized. Accordingly, we posit:

Proposition 1c. Strategic purchasing has a positive impact on reducing the inventory costs.

\subsection{Concurrent Engineering and Customer Responsiveness Time}

In order to meet the uncertainties in customer demands, concurrent engineering practices have evolved during the product development stage. In product design, improvement in quality is sought by gathering customer feedback, reducing the total number of components and, thereby, increasing reliability (Flynn, Sakakibara \& Schroeder, 1995). It has been mentioned that the overall quality improves because of the formation and the greater involvement of cross-functional teams. Implementation of CE leads to sharing of important information, which leads to improvement in factors such as manufacturability and complexity. This is further associated with improvement in customer responsiveness time and better performance in quality (Putnam, 1985; Whitney, 1988). This leads us to the following:

Proposition 2. Concurrent engineering practices have a positive impact on customer response time.

\subsection{Long-Term Relationships, Reduced Inventory Cost, Delivery Flexibility and Customer Responsiveness Time}

In order to be globally competitive, firms within the supply chain have started establishing extended relationships with buyers and suppliers who are part of the supply chain (Pitta, Franzak \& Little, 2004; Tan \& Wisner, 2003). This is essentially carried out with the sole purpose of offering lower cost products to customers with greater design and delivery flexibility (Tan \& Wisner, 2003). The importance of the formation of effective supplier alliances which involve working closely for mutual benefits is well documented in literature (Fung, 1999; Leonidou \& Kaleka, 1998; Shin et al. 2000; Tan et al., 1998).

Engaging in long-term relationships with customers, and even integrating customers in the supply chain, will help meet the customer demands effectively and minimize the existing inventory. In a long-term relationship environment, the suppliers would be committed to meet customer demands and the customers would be encouraged actively to provide feedback of their needs and concerns (Zeller \& Gillis, 1995). This would help improve responsiveness time. Trust and commitment, which are integral parts of long-term relationships, are known to have a positive influence on customer responsiveness and firm performance (Fynes, Voss \& Burca, 2005). Communication is an important dimension of a long-term relationship (Leonidou \& Kaleka, 1998). Effective communication between different component units of a supply chain leads to better coordination and has been shown to improve customer responsiveness and firm performance (Liu \& Wang, 1999; Pitta et al., 2004). In addition, long-term relationships as a whole have also been associated with improved customer responsiveness (Edget \& Snow, 1997).

Long-term relationships help in the effective flow of information and material thereby facilitating delivery flexibility (Ernst \&Whinney, 1987). With increasing uncertainty, such as variation in customer demands and reduction in product cycle time, there is a need to develop delivery flexibility. In order to successfully maintain delivery flexibility, different member constituents of the supply chain should integrate and coordinate effectively (Vickery et al., 1999). Also it has been noted that long term relationships and effective information-sharing between different units such as distribution mode, delivery channel, and vehicle scheduling have a positive impact on delivery performance in terms of flexibility (Vickery et al., 1999). 
This leads us to:

Proposition 3a. Long- term relationships have a positive impact on customer responsiveness time.

Proposition 3b. Long-term relationships have a positive impact on reducing inventory cost.

Proposition 3c. Long-term relationships have positive impact on delivery flexibility.

4.6 Delivery flexibility, reduced inventory costs and customer responsiveness time

Delivery flexibility has various advantages such as enabling the introduction of new products to market, reduction in lead times, reduction in costs associated with inventory levels, and delivery of product in a timely manner (Zhang, Vonderembse, \& Lim, 2006). A flexible delivery system helps a supply chain eliminate bottlenecks and adjust the levels of inventory stocks according to the needs of the customer (Kim \& Rogers, 2005). In addition, it has been mentioned that the advantages of flexible supply chain systems include enhanced customer satisfaction, reduction of back orders and improvement in response to new markets/competitors (Beamon, 1999). Accordingly we posit:

Proposition 4a. Delivery flexibility has a positive impact on reduced inventory costs.

Proposition $4 \mathrm{~b}$. Delivery flexibility has a positive influence on customer responsiveness time.

Proposition 4c. Delivery flexibility is positively associated with customer satisfaction

\subsection{Customer Responsiveness Time, Financial Performance, and Customer Satisfaction}

Organizations that develop good customer relations and focus on effective customer responses attain a distinctive edge in the industry (Tan et al., 1999). Greater customer loyalty, satisfaction and willingness to pay a premium price for higher product quality are some of the benefits associated with superior customer responsiveness (Stalk \& Hout, 1990). A supply chain that incorporates a customer driven corporate mission has been known to achieve a minimization of inventory and cycle time, as well as improvements in customer satisfaction and market share (Tan et al., 1999). Improved customer time responsiveness was found to enhance customer satisfaction and increase firm's financial performance (Corbett, 1992). Accordingly we posit the following:

Proposition 5. Customer responsiveness time is positively associated with customer satisfaction.

It has been established that it is important for each level of the supply chain to synchronize the use of inventory (Morgan, 2004; Stewart, 1995). This would further help in improving the logistical activities and help in the minimization of cost and improvement of a firm's financial performance in terms of costs saved on maintenance of excess inventory (Morgan, 2004). Hence we propose:

Proposition 6. Reduced inventory costs are associated with improved financial and market performance of the firm.

\subsection{Customer Satisfaction and Financial\& market performance}

The dimension of customer satisfaction indicates that the customer is satisfied and this also implies customer loyalty and higher customer reliability in buying. Customer satisfaction leads further to improvement financial performance (Hallowel, 1996; Levesque \& McDougall, 1996; Storbacka, Strandvik \& Gronroos, 1994; Urban \& Star, 1991). The more loyal customers are to the organization, the stronger the possibility of the retention of customers in the organization and greater the profits (Levesque \& McDougall, 1996). Hence we propose:

Proposition 7. Customer satisfaction has a positive influence on financial and market performance.

\section{Discussion and Implications for managers}

The SCM literature stands at crossroads. In order to enhance the knowledge development researchers have called for overarching frameworks (Burgess, Singh \& Koroglu, 2006; Lambert et al., 2005; Min \& Mentzer, 2004; S.Li et al., 2005). As mentioned by Emberson, Storey, Godsell and Harrison (2006), the challenge for supply chain management lies in understanding the interplay and alignment of different units of the supply chain. In addition, the potential of the supply chain can only be realized if the potential linkages between different components of the supply chain are understood (Burgess et al. 2006; Min \& Mentzer, 2004; S.Li et al., 2005, 2006; Zailani \& Rajagopal, 2005). As indicated before researchers have tried to understand the broad construct of supply chain management. For instance, some studies link SCM enablers such as information technology, to improved organizational performance (Boubekri, 2001; Marien, 2000; Motwani, Madan, \& Gunasekaran, 2000). In addition, some consider only specific aspects such as marketing, logistics and firm culture as important to overall supply chain success (Mello \& Stank, 2005; Mentzer et al., 2004; Min \& Mentzer, 2000; Svensson, 2002). Others, such as S.Li et al. (2006), explore the relationship between SCM, competitive advantage and 
organizational performance as a whole. To this end, researchers, so far, have failed to agree on two main aspects. First, what essentially constitutes the dimensions of supply chain management and second, how does supply chain management impact SCM performance and what impact does SCM performance has on the overall organizational performance. The purpose of this study was to propose a framework which offered managers insights into these issues.

In terms of the resource-based view, firms are viewed as a bundle of resources (Barney, 1991). These resources make the firm unique and offer the firm a unique advantage. In addition, the resources also differentiate the firm from its competitors (Barney, 1991). It becomes important for SCM managers to identify potentially important areas which need to be managed efficiently. The overall findings will reveal significant positive relationships between underlying dimensions of SCM dimensions, SCM performance and organizational performance. On a macro level the theoretical framework developed in the study will be the first of its kind to explore the relationships between SCM dimensions, SCM performance and organizational performance.

On a micro level the study also offers interesting implications for the managers. Purchasing has been viewed as an essential component of supply chain management. As mentioned previously, literature classifies purchasing into two categories: strategic and non-strategic (Murray, 2001). This study would further support the view that strategic purchasing would enhance supply chain performance. The positive relationship between strategic purchasing and long-term relationship and concurrent engineering provide interesting perspectives for managers. Long-term relationships have long been identified as important factors in the success of SCM (Jayaram, Kannan \& Tan, 2004; Moberg \& Speh, 2003). The notion that strategic purchasing will enhance long- term relationships further corroborates the importance of implementing strategic purchasing in firms implementing SCM. The findings of the study will further highlight the importance of maintaining close working relationships with specific suppliers and maintaining effective communication among selected suppliers.

To the best of our knowledge, the relationship between strategic purchasing and concurrent engineering has not been explored either conceptually or empirically. With the increasing popularity of concurrent engineering and the integration of different functional units in firms this dimension of SCM needs further investigation. Due to the importance of the formation of cross functional teams in concurrent engineering, managers will be presented with problems of selection of different functional units in the supply chain. The selection of suppliers who specifically meet the quality requirements will further improve the performance of cross-functional teams and overall concurrent engineering practices. Knowledge sharing and transfer will occur if the members of the team share common goals. This will further result in improved organizational learning and SCM performance. This aspect is highlighted by the support of the proposition.

The linkage between SCM dimensions and SCM performance reveal significant findings. The positive relationships between concurrent engineering and customer responsiveness time further strengthens the view that concurrent engineering is essential for meeting customer demands. In the scenario of uncertain demand, it is important to respond to the customer demands. During the project development phase, members are required to adhere to the strategic goals of the organization. As mentioned by Tan and Vonderembse (2006), concurrent engineering has been viewed as an important activity, especially as customer expectations grow and the importance of product development increases. Results of the study would also indicate that managing long-term relationships and implementing concurrent engineering would further improve the SCM performance in terms of flexibility specifically, delivery flexibility, inventory cost reduction and customer responsiveness time.

To the best of our knowledge, the linkage between SCM performance measures and organizational performance has not been explored in any other study. Managers when comprehended with different scenarios need adequate understanding of these linkages. The strategic vision of the entire supply chain must be in line with overall firm's vision, need and goals. In today's competitive world understanding the linkages helps managers to adapt to a specific situation and modify the working of specific component to achieve the desired results. For instance, the support for positive linkage between delivery flexibility and customer satisfaction would further stress on the fact that customers might view flexibility favorable as compared to other important measure such as cost involved. As proposed in the current study, managing delivery flexibility can in turn have a positive impact on inventory cost reduction and customer responsiveness time. Managers can reconfigure the supply chains to accommodate the flexibility component in order to fulfill the aim of achieving reduced inventory and improved customer responsiveness.

\section{Conclusion, Limitations and Future research}

In the current decade where competition is no longer between organizations but between their supply chains, it becomes imperative to have knowledge of various factors involved in the management of the supply chains. The 
motivation to carry out this study was the fact that even though organizations implement SCM, there has been evidence of failure of supply chains. This study is specifically designed to provide managers with an overarching framework for effective implementation of SCM. Until now, a plethora of studies have documented the importance of SCM performance (Beamon, 1999; Betchel \& Jayaram, 1997; Christopher \& Towill, 2000; Felix, Q. Chan., H. Chan., Henry, Lau \& Ip, 2003; Hofman, 2004; Ranganathan, Dhaliwal, Teo \& Thompson, 2004). The topic of identifying SCM dimensions and its linkage to organization performance has also gained importance (Chen \& Paulraj, 2004a, 2004b; Hsu, Tan, Kannan \& Keong, 2009; Li et al., 2006; Min \& Mentzer, 2004). In addition, these studies fail to address how SCM dimensions are related to SCM performance and, more importantly, how the dimensions of SCM performance are related to organization performance. In other words, the mediating impact of SCM performance between SCM strategies/dimensions and organization performance has gone unnoticed and deserves immediate attention (Green et al., 2006). To achieve the objective, an integrated framework was presented. The findings in the current study would support positive relationships between SCM dimensions, SCM performance measures and organizational performance measures.

The most significant limitation of the study is that it is conceptual in nature. Empirical support for the previously mentioned propositions is imperative to achieve validity and generalizability of the study.

Studies in the SCM development area have recognized the broad area under SCM and have mentioned, time and again, the difficulty of inclusion of all related dimensions of SCM (Chen \& Paulraj, 2004; Li et al., 2005, 2006). Other important SCM dimensions such as implementation of TQM (Tan et al., 2002), postponement (Li et al., 2006), and Just In Time (JIT) can also be considered. Future research could consider additional important SCM dimensions such as logistics, supply network coordination, mass customization, and geographic proximity in their analysis. In addition, additional SCM tools such as top management support and information technology can also be considered and its impact on SCM dimensions could be analyzed. It would also be interesting to carry out the study both in developing economies and developed economies and study the implications for SCM managers in these economies. There also has been a call for empirical research in investigating SCM performance measures (Barad \& Sapir, 2003; Garavelli, 2003).

Additional SCM performance measures such as improved quality and reduced overall cost may be integrated into the framework, and their impact on organizational performance can also be studied. In addition, firms can be divided into high tech and low tech firms and the difference in results can also be studied. This might be critical as SCM has strategic implications both at the firm level and the supply chain levels. In addition, as recognized by Trent (2004), contrary to the popular notion that effective supply chain management is only in the hands of managers, this research proposes that, in order to achieve a successful implementation of the supply chain, all units of the supply chain should fully embrace and understand the strategy. Finally, the framework is believed to offer SCM managers a means to identify factors and effectively implement SCM.

\section{References}

Agarwal, A., \& Shankar, R. (2002). Analyzing alternatives for improvement in supply chain performance. Work Study, 51(1), 32-37. http://dx.doi.org/10.1108/00438020210415497

Alexander, M. (1985). Creative marketing and innovative consumer product design - some case studies. Design Studies, 6(1), 41-50. http://dx.doi.org/10.1016/0142-694X(85)90040-7

Alvarado, U. Y., \& Kotzab, H., 2001. Supply chain management: The integration of logistics in marketing. Industrial Marketing Management, 30(2), 183-198. http://dx.doi.org/10.1016/S0019-8501(00)00142-5

Ansoff, H. I., \& Sullivan, P. A. (1993). Optimizing profitability in turbulent environments: A formula for strategic success. Long Range Planning, 26(5), 11-23. http://dx.doi.org/10.1016/0024-6301(93)90073-O

Anumba, C. J., Siemienmuch, C. F., \& Sinclair, M. A. (2000). Supply chain implications of concurrent engineering. International Journal of Physical Distribution \& Logistics Management, 30(7/8), 566-597. http://dx.doi.org/10.1108/09600030010346233

Arzu Akyuz, G., \& Erman Erkan, T. (2010). Supply chain performance measurement: a literature review. International Journal of Production Research, 48(17), 5137-5155. http://dx.doi.org/10.1080/00207540903089536

Barad, M., \& Sapir, D. (2003). Flexibility in logistic systems-modeling and performance evaluation. $\begin{array}{lllr}\text { International Journal of Production } & \text { Economics, } & 85(2), & \text { 155-170. }\end{array}$ http://dx.doi.org/10.1016/S0925-5273(03)00107-5

Barney, J. (1991). Firm resources and sustained competitive advantage. Journal of Management, 17(1), 99-120. 
http://dx.doi.org/10.1177/014920639101700108

Beamon, B. M. (1999). Measuring supply chain performance. International Journal of Operations \& Production Management, 19(3), 275-292. http://dx.doi.org/10.1108/01443579910249714

Bechtel, C., \& Jayaram, J. (1997). Supply chain management-A strategic perspective. The International Journal of Logistics Management, 8(1), 15-34. http://dx.doi.org/10.1108/09574099710805565

Bode, C., Wagner, S. M., Petersen, K. J., \& Ellram, L. M. (2011). Understanding Responses To Supply Chain Disruptions: Insights From Information Processing And Resource Dependence Perspectives. Academy of Management Journal, 54(4), 833-856. http://dx.doi.org/10.5465/AMJ.2011.64870145

Boubekri, N. (2001). Technology enablers for supply chain management. Integrated Manufacturing Systems, 12(6), 394-399. http://dx.doi.org/10.1108/EUM0000000006104

Bradley, D. (1995). Concurrent engineering for bespoke products. Assembly Automation, 15(1), 35-37. http://dx.doi.org/10.1108/EUM0000000004225

Brookshaw, T., \& Terziovski, M. (1997). The relationship between strategic purchasing and customer satisfaction within a total quality management environment. Benchmarking: An International Journal, 4, 244-258.

Burgess, K., Singh, P. J., \& Koroglu, R. (2006). Supply chain management: A structured literature review and implications for future research. International Journal of Operations \& Production Management, 26(7), 703-729. http://dx.doi.org/10.1108/01443570610672202

Buzzel, R. D., Gale, B. T., \& Sultan, R. G. (1975). Market Share - A key to profitability. Harvard Business Review, 53, 97-106.

Campbell, N. (1985). An interaction approach to organizational buying behavior. Journal of Business Research, 13(1), 35-48. http://dx.doi.org/10.1016/0148-2963(85)90012-8

Carr, A. S., \& Pearson, J. N. (2002). The impact of purchasing and supplier involvement on strategic purchasing and its impact on firm's performance. International Journal of Operations \& Production Management, 22(9), 1032-1053. http://dx.doi.org/10.1108/01443570210440528

Carr, A., \& Pearson, J. (1999). Strategically managed buyer-supplier relationships and performance outcomes. Journal of Operations Management, 17(5), 497-519. http://dx.doi.org/10.1016/S0272-6963(99)00007-8

Castaldi, C., Ten Kate, C., \& Den Braber, R. (2011). Strategic purchasing and innovation: A relational view. $\begin{array}{lllll}\text { Technology Analysis \& Strategic } & \text { Management, } & 23(9), & 983-1000 .\end{array}$ http://dx.doi.org/10.1080/09537325.2011.616699

Celtek, S., \& Kaynak, H. (1999). Characteristics of supply chain management: towards the development of a measurement instrument. Paper present at the second annual North American research symposium on purchasing and supply management.

Chen I. J., \& Paulraj, A. (2004b). Understanding supply chain management: critical research and a theoretical framework. International Journal of Production Research, 42(1), 131-163. http://dx.doi.org/10.1080/00207540310001602865

Chen, I. J., Paulraj, A., \& Lado, A. A. (2004). Strategic purchasing, supply management and firm performance. Journal of Operations Management, 22(5), 505-523. http://dx.doi.org/10.1016/j.jom.2004.06.002

Chen, I., \& Paulraj, A. (2004a). Towards a theory of supply chain management: the constructs and measurements. Journal of Operations Management, 22(2), 119-150. http://dx.doi.org/10.1016/j.jom.2003.12.007

Chopra, S., \& Meindl, P. (2001). Supply Chain Management-Strategy, Planning, Organization. Upper Saddle River: Prentice-Hall.

Christopher, M., \& Towill, D. R. (2000). Supply chain migration from lean and functional to agile and customized. Supply Chain Management: An International Journal, 5(4), 206-213. http://dx.doi.org/10.1108/13598540010347334

Christy, D. P., \& Grout, J. R. (1994). Safeguarding supply chain relationships. International Journal of Production Economics, 36(3), 233-242. http://dx.doi.org/10.1016/0925-5273(94)00024-7

Cigolini, R., Cozzi, M., \& Perona, M. (2004). A new framework for supply chain management: Conceptual model and empirical test. International Journal of Operations \& Production Management, 24(1), 7-41. http://dx.doi.org/10.1108/01443570410510979 
Closs, D. J., \& Mollenkopf, D. A. (2004). A global chain framework. Industrial Marketing Management, 41(6), 37-44. http://dx.doi.org/10.1016/j.indmarman.2003.08.008

Cohen, M. A., \& Lee, H. L. (1988). Strategic analysis of integrated production distribution systems: models and methods. Operations Research, 36(2), 216-228. http://dx.doi.org/10.1287/opre.36.2.216

Corbett, L. M. (1992). Delivery windows-a new view on improving manufacturing flexibility and on-time delivery performance. Production and Inventory Management Journal, 33, 74-9.

Cousins, P. D. (2005). The alignment of appropriate firm and supply strategies for competitive advantage. International Journal of Operations \& Production Management, 25(5), 403-428. http://dx.doi.org/10.1108/01443570510593120

Cunningham, M. T. (1982). Purchasing strategies in Europe: an interactive prespective of industrial buyer behavior. International Journal of Physical Distribution \& Materials Management, 12, 16-32.

Das, S. K., \& Abdel-Malek, L. (2003). Modeling the flexibility of order quantities and lead-times in supply chains. International Journal of Production Economics, 85(2), 171-181. http://dx.doi.org/10.1016/S0925-5273(03)00108-7

Divett, M., Crittenden, N., \& Henderson, R. (2003). Actively influencing consumer loyalty. Journal of Consumer Marketing, 20(2), 109-126. http://dx.doi.org/10.1108/07363760310464587

Donlon, J. P. (1996). Maximizing value in the supply chain. Chief Executive, 117, 54-63.

Dyer \& Singh. (1988). The relational view: cooperative strategy and sources of interorganizational competitive advantage. Academy of Management Review, 23, 660-79.

Edgett, S., \& Snow, K. (1997). Benchmarking measures of customer satisfaction, quality and performance for new financial service products. Journal of Product \& Brand Management, 6(4), 250-259. http://dx.doi.org/10.1108/10610429710186770

Ernst \& Whiney. (1987). Coorporate profitability and logistics: innovative guidelines for executives. Council of logistics Management: Oak Brook IL.

Feciková, I. (2004). An index method for measurement of customer satisfaction. The TQM Magazine, 16(1), 57-66. http://dx.doi.org/10.1108/09544780410511498

Felix, C. H., Q. Chan., H. Chan., Henry, C. W., Lau, R., \& Ip, W. L. (2003). A conceptual model of performance measurement for supply chains. Management Decision, 41(7), 635-642. http://dx.doi.org/10.1108/00251740310495568

Ferguson, W. C., Hartley, M. F., Turner, G. B., \& Pierce, E. M. (1996). Purchasing's role in corporate strategic planning. International Journal of Physical Distribution and Logistics Management, 26(4), 51-62. http://dx.doi.org/10.1108/09600039610116512

Flynn, B., Sakakibara, S., \& Schroeder, R. G. (1995). Relationship between JIT and TQM practices and performance. Academy of Management Journal, 38(5), 1325-1360. http://dx.doi.org/10.2307/256860

Francois, F., \& Gilles, P. (2005). Exploiting SCM as source of competitive advantage: The Importance of Cooperative Goals Revisited. $C R, 15,92-100$.

Fung, P. (1999). Managing purchasing in a supply chain context - evolution and resolution. Logistics Information Management, 12(5), 362-367. http://dx.doi.org/10.1108/09576059910295788

Fynes, B., Voss, C., \& Búrca, S. (2005). The impact of supply chain relationship dynamics on manufacturing performance. International Journal of Operations \& Production Management, 25(1), 6-19. http://dx.doi.org/10.1108/01443570510572213

Garavelli, A. (2003). Flexibility configurations for the supply chain management. International Journal of Production Economics, 85(2), 141-153. http://dx.doi.org/10.1016/S0925-5273(03)00106-3

Gilmour, P. (1999). A strategic audit framework to improve supply chain performance. Journal of Business \& Industrial Marketing, 14(5/6), 355-363. http://dx.doi.org/10.1108/08858629910290102

Godsell, J., Harrison, A., Emberson, C., \& Storey, J. (2006). Customer responsive supply chain strategy: An unnatural act?. International Journal of Logistics: Research \& Applications, 9(1), 47-56. http://dx.doi.org/10.1080/13675560500534664

Green, K. W., McGaughey, R., \& Casey, M. (2006). Does supply chain management strategy mediate the 
association between market orientation and organizational performance? Supply Chain Management Journal, 11(5), 407-414. http://dx.doi.org/10.1108/13598540610682426

Griffith, D. A., Harvey, M. G., \& Lusch, R. F. (2006). Social exchange in supply chain relationships: The resulting benefits of procedural and distributive justice. Journal of Operations Management, 24(2), 85-98. http://dx.doi.org/10.1016/j.jom.2005.03.003

Guinipero, L. \& Eltantawy, R. (2004). Securing the upstream supply chain: a risk management approach. International Journal of Physical Distribution \& Logistics Management, 34(9), 698-713. http://dx.doi.org/10.1108/09600030410567478

Gunasekaran, A. (1998). Concurrent Engineering: A Competitive Strategy for Process Industries. The Journal of the Operational Research Society, 49(7), 758-765. http://dx.doi.org/10.1038/sj.jors.2600549

Gunasekaran, A., \& Love, P. (1998). Concurrent engineering: a multi-disciplinary approach for construction. Logistics Information Management, 11(5), 295-300. http://dx.doi.org/10.1108/09576059810234209

Gunasekaran, A., Patel, C., \& Tirtiroglu, E. (2001). Performance measures and metrics in a supply chain environment. International Journal of Operations \& Production Management, 21(1/2), 71-87. http://dx.doi.org/10.1108/01443570110358468

Hallowell, R. (1996). The relationships of customer satisfaction, customer loyalty, and profitability: an empirical study. International Journal of Service Industry Management, 7(4), 27-32. http://dx.doi.org/10.1108/09564239610129931

Handfield, R. B., \& Nichols, E. L. Jr. (1998). An Introduction to supply chain management. Upper saddle river, NJ: Prentice Hall.

Handfield, R. B., Krause, D. R., Scannell, T. V., \& Monczka, R. M. (2000). Avoid the Pitfalls in Supplier Development. Sloan Management Review, 41, 37-49.

Harland, C. M. (1996). Supply chain management: relationships, chains and networks. British Journal of Management, 7(S1), S63-S80. http://dx.doi.org/10.1111/j.1467-8551.1996.tb00148.x

Harland, C. M., Lamming, R. C., \& Cousins, P. D. (1999). Developing the concept of supply strategy. International Journal of Operations \& Production Management, 19(7), 650-674. http://dx.doi.org/10.1108/01443579910278910

Harrison, A., \& Van Hoeck, R. (2002). Logistics Management and Strategy. Harlow: Prentice Hall.

Hofman, Debra. (2004). The hierarchy of supply chain matrices. Supply Chain Management Review, 8, 28-37.

Holmes, G. (1994). Putting Concurrent Engineering into Practice. World Class Design to Manufacture, 1(5), 38-42. http://dx.doi.org/10.1108/09642369210069814

Hsu, C. C., Tan, K. C., Kannan, V. R., \& Keong Leong, G. G. (2009). Supply chain management practices as a mediator of the relationship between operations capability and firm performance. International Journal of Production Research, 47(3), 835-855. http://dx.doi.org/10.1080/00207540701452142

Jamal, A., \& Naser, K. (2002). Customer satisfaction and retail banking: an assessment of some of the key antecedents of customer satisfaction in retail banking. International Journal of Bank Marketing, 20(4), 146-160. http://dx.doi.org/10.1108/02652320210432936

Jarvis, M. (1999). Concurrent Engineering. Work Study, 48(3), 88-91. http://dx.doi.org/10.1108/00438029910262464

Jayaram, J., Kannan, V. R., \& Tan, K. C., (2004). Influence of initiators on supply chain value creation. $\begin{array}{lllll}\text { International Journal of Production } & \text { Research, } & 42(20), & \text { 4377-4399. }\end{array}$ http://dx.doi.org/10.1080/00207540410001716516

Jayaram, J., Vickery, S., \& Droge, C. (2000). The effects of information system infrastructure and process improvements on supply-chain time performance. International Journal of Physical Distribution \& Logistics Management, 30(3), 314-330. http://dx.doi.org/10.1108/09600030010326082

Kim, J., \& Rogers, K. J. (2005). An object-oriented approach for building a flexible supply chain model. International Journal of Physical Distribution \& Logistics Management, 35(7), 481-502. http://dx.doi.org/10.1108/09600030510615815

Koufteros, X., Vondersembse, M., \& Doll, W. (2001). Concurrent engineering and its consequences. Journal of Operations Management, 19(1), 97-115. http://dx.doi.org/10.1016/S0272-6963(00)00048-6 
Krause, D. R., Handfield, R. B., \& Tyler, B. B. (2007). The relationships between supplier development, commitment, social capital accumulation and performance improvement. Journal of Operations Management, 25(2), 528-545. http://dx.doi.org/10.1016/j.jom.2006.05.007

Kumar,V., Fantazy, K. A., Kumar, U., \& Boyle, T. B. (2006). Implementation and management framework for supply chain flexibility. Journal of Enterprise Information Management, 19(3), 303-319. http://dx.doi.org/10.1108/17410390610658487

Lalonde, B. J. \& Pohlen, T. L. (1996). Issues in supply chain costing. The International Journal of Logistics Management, 7(1), 1-12. http://dx.doi.org/10.1108/09574099610805395

Lambert, D, M., Dastugue, S, J., \& Croxton, K, L. (2005). An evaluation of process oriented supply chain management framework. Journal of Business Logistics, 26, 25-51. http://dx.doi.org/10.1002/j.2158-1592.2005.tb00193.x

Lambert, D. M., Cooper, M. C., \& Pagh, J. D. (1998). Supply Chain Management: Implementation Issues and Research Opportunities. International Journal of Logistics Management, 9(2), 1-19. http://dx.doi.org/10.1108/09574099810805807

Lee, H. L., \& Billington, C. (1992). Managing supply chain inventory: pitfalls and opportunities. Sloan Management Review, 33, 65-73.

Lee, H. L., \& Billington, C. (1993). Material management in decentralize supply chains. Operations Research, 41(5), 835-847. http://dx.doi.org/10.1287/opre.41.5.835

Leonidou, L. C., \& Kaleka, A. A. (1998). Behavioral aspects of international buyer-seller relationships. Their association with export involvement. International Marketing Review, 15(5), 373-97. http://dx.doi.org/10.1108/02651339810236407

Levesque, T., \& McDougall, G. (1996). Determinants of customer satisfaction in retail banking. International Journal of Bank Marketing, 14(7), 12-20. http://dx.doi.org/10.1108/02652329610151340

Li, S., Nathan, B. R., Nahan, T. S. \& Rao, S. S. (2005). Development and validation of a measurement instrument for studying supply chain management practices. Journal of Operations Management, 23(6), 618-641. http://dx.doi.org/10.1016/j.jom.2005.01.002

Li, S., Nathan, B. R., Nathan, T. S., \& Rao, S, S. (2006). The impact of supply chain management practices on competitive advantage and organizational performance. Omega, 34(2), 107-124. http://dx.doi.org/10.1016/j.omega.2004.08.002

Liu, H., \& Wang, Y. P. (1999), Co-ordination of international channel relationships: four case studies in the food industry in China. Journal of Business \& Industrial Marketing, 14(2), 130-50. http://dx.doi.org/10.1108/08858629910259008

Lockamy, A. III., \& McCormack, K. (2004). Linking SCOR planning practices to supply chain performance: An exploratory study. International Journal of Operations \& Production Management, 24(12), 1192-1218. http://dx.doi.org/10.1108/01443570410569010

Malik M. A., Khalfan., Anumba, C. J., Siemieniuch, C. E., \& Sinclair, M. A. (2001). Readiness Assessment of the construction supply chain for concurrent engineering. European Journal of Purchasing \& Supply Management, 7(2), 141-153. http://dx.doi.org/10.1016/S0969-7012(00)00023-X

Malik, Y., Niemeyer, A., \& Ruwadi, B. (2011). Building the supply chain of the future. Mckinsey Quarterly, (1), 62-71.

Marien, E. J. (2000). The four Supply Chain enablers. Supply Chain Management Review, 4, 60-69.

Mello, J. E., \& Stank, P. T. (2005). Linking firm culture and orientation to supply chain success. International Journal of Physical Distribution \& Logistics Management, 35(8), 542-554. http://dx.doi.org/10.1108/09600030510623320

Mentzer, J. T., DeWitt, W., Keebler, J. S., Soonhoong, M., Nix, N. W., Smith, C. D., \& Zacharia, Z. G. (2001). Defining supply chain management. Journal of Business Logistics, 22(2), 1-25. http://dx.doi.org/10.1002/j.2158-1592.2001.tb00001.x

Mentzer, J. T., Min, S., \& Zacharia, Z. G. (2004). The nature of inter-firm partnering in supply chain management. Journal of Retailing, 76(4), 549-568. http://dx.doi.org/10.1016/S0022-4359(00)00040-3

Min, S., \& Mentzer, J. T. (2000). The role of marketing in supply chain management. International Journal of 
Physical Distribution \& Logistics Management, 30(9), 765-786. http://dx.doi.org/10.1108/09600030010351462

Min, S., \& Mentzer, J. (2004). Developing and measuring supply chain management concepts. Journal of Business Logistics, 25(1), 63-92. http://dx.doi.org/10.1002/j.2158-1592.2004.tb00170.x

Moberg, C. B., Speh, T. W., \& Freese, T. L. (2003). SCM: Making the Vision a Reality. Supply Chain Management Review, 7, 34-40.

Moberg, C. R., \& Speh, T. W. (2003). Evaluating the relationship between questionable business practices and the strength of supply chain relationships. Journal of Business Logistics, 24(2), 1-19. http://dx.doi.org/10.1002/j.2158-1592.2003.tb00043.x

Morgan, C. (2004). Structure, speed and salience: performance measurement in the supply chain. Business Process Management Journal, 10(5), 522-536. http://dx.doi.org/10.1108/14637150410559207

Motwani, J., Madan, M., \& Gunasekaran, A. (2000). Information technology in managing global supply chains. Logistics Information Management, 13(5), 320-327. http://dx.doi.org/10.1108/09576050010378540

Murray, K. G. (2001). Improving purchasing's contribution - The purchasing strategy of buying council. International Journal of Public Sector Management, $14(5), \quad 391-410$. http://dx.doi.org/10.1108/EUM000000005567

Neely, A., Gregory, M., \& Platts, K. (1995). Performance measurement system design. International Journal of Operations \& Production Management, 15(4), 80-116. http://dx.doi.org/10.1108/01443579510083622

Olkkonen, R., Tikkanen, H., \& Alajoutsijärvi, K. (2000). Sponsorship as relationships and networks: implications for research. Corporate Communications: An International Journal, 5(1), 12-19. http://dx.doi.org/10.1108/13563280010317532

Piplani, R., \& Fu, Y. F. (2005). A coordination framework for supply chain inventory alignment. Journal of Manufacturing Technology, 16(6), 598-614. http://dx.doi.org/10.1108/17410380510609465

Pitta, D. A., Franzak, F. L., \& Little, M. W. (2004). Maintaining positive returns in the value and supply chain: applying tomorrow's marketing skills. Journal of Consumer Marketing, 21(7), 510-519. http://dx.doi.org/10.1108/07363760410568725

Putnam, A. O. (1985). A redesign for engineering. Harvard Business Review, 63, 139-144.

Pyke, D. F., \& Cohen, M. A. (1994). Multi-product integrated production-distribution systems. European Journal of Operational Research, 74(1), 18-49. http://dx.doi.org/10.1016/0377-2217(94)90201-1

Ranganathan, C., Dhaliwal, J. S., Teo, R., \& Thompson S. H. (2004). Assimilation and Diffusion of Web Technologies in Supply-Chain Management: An Examination of Key Drivers and Performance Impacts. International Journal of Electronic Commerce, 9, 127-161.

Salvador, F., Cipriano, F., Rungtusanatham, M., \& Choi, T. Y. (2001). Supply chain interactions and time related performance: An operations management perspective. International Journal of Operations \& Production Management, 21(4), 461-475. http://dx.doi.org/10.1108/01443570110381372

Sánchez, A. M., \& Pérez, M. P. (2005). Supply chain flexibility and firm performance: A conceptual model and empirical study in the automotive industry. International Journal of Operations \& Production Management, 25(7), 681-700. http://dx.doi.org/10.1108/01443570510605090

Scannel T, V., Vickery, S., \& Droge, C. (2000). Upstream supply chain management and competitive performance in the automotive supply industry. Journal of Business Logistics, 21, 23-48.

Sharifi, S., \& Pawar, K. S. (2002). Virtually co-located product design teams: Sharing teaming experiences after the event? International Journal of Operations \& Production Management, 22(6), 656-679. http://dx.doi.org/10.1108/01443570210427677

Shin, H., Collier, D. A., \& Wilson, D. D. (2000). Supply management orientation and supplier-buyer $\begin{array}{lllll}\text { performance. Journal of } & \text { Operations } & \text { Management, } & 18(3), & 333 .\end{array}$ http://dx.doi.org/10.1016/S0272-6963(99)00031-5

Siemieniuch, C. E., \& Sinclair, M. A. (1999). Implications of the supply chain for role definitions in concurrent engineering. International Journal of Human Factors and Ergonomics in Manufacturing, 10(3), 251-272. http://dx.doi.org/10.1002/1520-6564(200022)10:3<251::AID-HFM3>3.0.CO;2-Q

Sinclair, M. A. et al. (1995). A discussion of simultaneous engineering and the manufacturing supply chain from an ergonomics perspective. International Journal of Industrial Engineering, 16, 263-282. 
Stalk, G., \& Hout, T. M. (1990). Competing Against Time: How Time-based Competition is Reshaping Global Markets. New York, NY: The Free Press.

Stewart, G. (1995). Supply chain performance benchmarking study reveals keys to supply chain excellence. Logistics Information Management, 8(2), 38-44. http://dx.doi.org/10.1108/09576059510085000

Storbacka, K., Strandvik, T., \& Grönroos, C. (1994). Managing customer relationships for profit: the dynamics of relationship quality. International Journal of Service Industry Management, 5(5), 21-38. http://dx.doi.org/10.1108/09564239410074358

Styles, C., \& Amber, T. (2000). The impact of relations variable on export performance: An empirical investigation in Australia and UK. Australian Journal of Management, 25(3), 261-281. http://dx.doi.org/10.1177/031289620002500302

Svensson, G. (2002). The theoretical foundation of supply chain management: A functionalist theory of marketing. International Journal of Physical Distribution \& Logistics Management, 32(9), 734-754. http://dx.doi.org/10.1108/09600030210452422

Tan, C., \& Vonderembse, M. A. (2006). Mediating effects of computer-aided design usage: From concurrent engineering to product development performance. Journal of Operations Management, 24(5), 494-510. http://dx.doi.org/10.1016/j.jom.2005.11.007

Tan, K. C., Kannan, V. R., \& Handfield, R. B. (1999). Supply chain management: an empirical study of its impact on performance. International Journal of Operations \& Production Management, 19(10), 1034-1052. http://dx.doi.org/10.1108/01443579910287064

Tan, K. C., Kannan, V. R., \& Handfield, R. B. (1998). Supply chain management: supplier performance and firm performance. International Journal of Purchasing and Materials Management, 34, 2-9.

Tan, K. C., Lyman, S. B., \& Wisner, J. D. (2002). Supply chain management: a strategic perspective. International Journal of Operations and Production Management, 22(6), 614-631. http://dx.doi.org/10.1108/01443570210427659

Tan, K. C., \& Wisner, J. D. (2003). A study of operations management constructs and their relationships. International Journal of Operations \& Production Management, 23(12), 1300-1325. http://dx.doi.org/10.1108/01443570310501862

Tracey, M., Chong Leng, T., Vonderembse, M., \& Bardi, E. J. (1995). A Reexamination of the Effects of Just-In-Time on Inbound Logistics. International Journal of Logistics Management, 6(2), 25-37. http://dx.doi.org/10.1108/09574099510805323

Tracey, M., Lim, J. S., \& Vonderembse, M. A. (2005) The impact of supply chain management capabilities on $\begin{array}{lllll}\text { organization } & \text { performance. } & \text { Supply Chain } & \text { Management, } & \text { 10(3), }\end{array}$ http://dx.doi.org/10.1108/13598540510606232

Trent, R. J. (2004). What everyone needs to know about SCM. Supply Chain Management Review, 8, 52-59.

Uncles, M. D., Dowling, G. R., \& Hammond, K. (2003). Customer loyalty and customer loyalty programs. Journal of Consumer Marketing, 20(4), 294-316. http://dx.doi.org/10.1108/07363760310483676

Urban, G., \& Star, S. (1991). Advanced Marketing Strategy. London: Prentice-Hall.

Venkatraman, N., \& Ramanujan, V. (1987). Measurement of business economic performance: An examination of method convergence. Journal of Management, 13(1), 109-122. http://dx.doi.org/10.1177/014920638701300109

Vickery, S, K., Jayaram, J., Droge, C., \& Calantone, R. (2003). The effects of an integrative supply chain chain strategy on customer service and financial performance: an analysis of direct versus indirect relationships. Journal of Operations Management, 21(5), 523-539. http://dx.doi.org/10.1016/j.jom.2003.02.002

Vickery, S., Calantone, R., \& Dröge, C. (1999). Supply Chain Flexibility: An Empirical Study. Journal of Supply Chain Management: A Global Review of Purchasing \& Supply, 35(3), 16-24. http://dx.doi.org/10.1111/j.1745-493X.1999.tb00058.x

Whitney, D. E. (1988). Manufacturing by design. Harvard Business Review, 66, 83-91.

Williams, R., \& Visser, R. (2002). Customer satisfaction: it is dead but it will not lie down. Managing Service Quality, 12(3), 194-200. http://dx.doi.org/10.1108/09604520210429268

Wisner, J. D. (2003). A structural equation model of supply chain management strategies and firm performance. Journal of Business Logistics, 24(1), 1-26. http://dx.doi.org/10.1002/j.2158-1592.2003.tb00030.x 
Zailani, S., \& Rajagopal, P. (2005). Supply chain integration and performance: UK versus East Asian companies. Supply chain Management: An International Journal, 10, 379-373.

Zeller, T. L., \& Gillis, D. M. (1995). Achieving market excellence through quality: The case of Ford Motor Company. Business Horizons, 38(3), 23-33. http://dx.doi.org/10.1016/0007-6813(95)90019-5

Zhang, Q., Vonderembse, M. A., \& Lim, J. (2006). Spanning flexibility: supply chain information dissemination drives strategy development and customer satisfaction. Supply Chain Management: An International Journal, 11(5), 390-399. http://dx.doi.org/10.1108/13598540610682408

Zhang, Z., \& Sharifi, H. (2000). A methodology for achieving agility in manufacturing organizations. International Journal of Operations \& Production Management, 20(4), 496-513. http://dx.doi.org/10.1108/01443570010314818

Table 1A. Studies indicating Different Dimensions of Supply Chain Management

\begin{tabular}{|c|c|c|c|c|c|c|}
\hline Study & TQM & JITP & $\begin{array}{l}\text { Supply network } \\
\text { coordination }\end{array}$ & $\begin{array}{l}\text { Customer } \\
\text { relationship }\end{array}$ & Logistics & $\begin{array}{r}\text { Information } \\
\text { technology }\end{array}$ \\
\hline Sinclair, et al., 1995 & No & No & No & No & No & No \\
\hline $\begin{array}{l}\text { Malik, Khalfan, Anumba, } \\
\text { Siemieniuch and Sinclair (2001) }\end{array}$ & No & No & No & No & No & No \\
\hline Balasubramanium (2001) & No & No & No & No & No & No \\
\hline Chen and Paulraj (2004a) & No & No & Yes & No & Yes & Yes \\
\hline Chen and Paulraj, 2004b & No & No & Yes & No & Yes & Yes \\
\hline S.Li et al., 2005 & No & No & Yes & Yes & Yes & No \\
\hline Mentzer and Min (2004) & No & No & No & No & No & Yes \\
\hline Cigoline, Cozzi and Perona (2004) & No & Yes & No & Yes & No & Yes \\
\hline Tan, Lyman and Wisner (2002) & No & Yes & Yes & Yes & No & Yes \\
\hline Alvarado and Kotzab (2001) & No & No & No & No & No & No \\
\hline Kaynak and Celtek (1999) & Yes & Yes & No & No & Yes & Yes \\
\hline Harland (1996) & No & Yes & No & No & Yes & No \\
\hline Closs and Mollenkopf (2004) & No & No & No & Yes & Yes & Yes \\
\hline Siemieniuch and Sinclair (1999) & No & No & No & No & No & No \\
\hline Gunasekaran and Love (1998) & No & No & No & No & No & No \\
\hline $\begin{array}{l}\text { Anumba,Siemieniuch and Sinclair } \\
(2000)\end{array}$ & No & No & No & No & No & Yes \\
\hline Chen, Paulraj and Lado (2004) & No & No & No & No & No & No \\
\hline Li et al. (2006) & No & No & No & Yes & Yes & No \\
\hline Carr and Pearson (1999) & No & No & No & No & No & No \\
\hline
\end{tabular}


Table 1B. Other Dimensions of Supply Chain Management for the Studies Considered Above

\begin{tabular}{|c|c|c|c|c|c|}
\hline Study & $\begin{array}{l}\text { Long term } \\
\text { relationships }\end{array}$ & $\begin{array}{c}\text { Strategic } \\
\text { purchasing }\end{array}$ & $\begin{array}{c}\text { Supply } \\
\text { management }\end{array}$ & $\begin{array}{l}\text { Concurrent } \\
\text { Engineering }\end{array}$ & $\begin{array}{l}\text { Information } \\
\text { Sharing }\end{array}$ \\
\hline Sinclair et al. (2005) & Yes & Yes & No & Yes & No \\
\hline $\begin{array}{l}\text { Malik, Khalfan, Anumba, } \\
\text { Siemieniuch and Sinclair } \\
\text { (2001) }\end{array}$ & No & No & No & Yes & No \\
\hline Balasubramanium (2001) & No & No & No & Yes & No \\
\hline Chen and Paulraj (2004a) & Yes & Yes & Yes & No & Yes \\
\hline Chen and Paulraj, 2004b & Yes & Yes & Yes & No & Yes \\
\hline S.Li et al., 2005 & No & Yes & Yes & No & Yes \\
\hline Mentzer and Min (2004) & Yes & No & No & No & Yes \\
\hline Cigoline et al. (2004) & No & Yes & No & No & No \\
\hline Tan et al. (2002) & Yes & No & No & No & No \\
\hline Alvarado and Kotzab (2001) & Yes & No & No & No & No \\
\hline Kaynak and Celtek (1999) & No & No & No & Yes & Yes \\
\hline Harland (1996) & Yes & No & No & No & No \\
\hline $\begin{array}{l}\text { Closs and Mollenkopf } \\
\text { (2004) }\end{array}$ & Yes & No & Yes & No & No \\
\hline $\begin{array}{l}\text { Siemieniuch and Sinclair } \\
\text { (1999) }\end{array}$ & No & No & No & Yes & No \\
\hline $\begin{array}{l}\text { Gunasekaran and Love } \\
\text { (1998) }\end{array}$ & No & No & No & Yes & No \\
\hline $\begin{array}{l}\text { Anumba,Siemieniuch \& } \\
\text { Sinclair (2000) }\end{array}$ & No & No & No & Yes & No \\
\hline Carr and Pearson 1999 & Yes & Yes & No & No & No \\
\hline S.Li et al. 2006 & Yes & No & Yes & No & Yes \\
\hline $\begin{array}{l}\text { Chen, Paulraj and Lado } \\
\text { (2004) }\end{array}$ & No & Yes & Yes & No & No \\
\hline
\end{tabular}


Table 2. Identification of SCM Performance Measures using different studies

\begin{tabular}{|c|c|}
\hline Study & Supply chain performance matrices used \\
\hline Beamon (1999) & $\begin{array}{l}\text { Resource, output and flexibility measures } \\
\text { Resource measures include inventory level, cost, energy usage, personnel } \\
\text { requirements, and equipment utilization. } \\
\text { Output measures include customer satisfaction, product quality, time } \\
\text { required to produce a particular item or set of items; and number of } \\
\text { on-time deliveries. } \\
\text { Use the operationalization by Slack (1991) who identify two types of } \\
\text { flexibilities: range flexibility and response flexibility. } \\
\text { Volume, reliability, Delivery, mix and new product flexibility were the } \\
\text { flexibility to be explored. }\end{array}$ \\
\hline Jayaram (1999) & $\begin{array}{l}\text { Delivery speed, delivery reliability, new product introduction, new } \\
\text { product development time, manufacturing lead-time, and customer } \\
\text { responsiveness (CR). }\end{array}$ \\
\hline Felix et al. (2003) & $\begin{array}{l}\text { Cost, time, Capacity, flexibility, Capability, productivity, outcome and } \\
\text { utilization }\end{array}$ \\
\hline $\begin{array}{l}\text { Lockamy III and } \\
\text { McCormack (2004) }\end{array}$ & Cost, quality, efficiency \\
\hline Lalonde and Pohlen (1996) & Cost of ownership and cost of productivity \\
\hline $\begin{array}{l}\text { Betchel and Jayaram } \\
\text { (1997) }\end{array}$ & Total response time, customer responsiveness \\
\hline $\begin{array}{l}\text { Zailani and Rajagopal } \\
\text { (2005) }\end{array}$ & $\begin{array}{l}\text { Quality(includes ability to deliver products in time, meeting devliery } \\
\text { times), Delivery speed, Delivery reliability, customer relationships, } \\
\text { flexibility }\end{array}$ \\
\hline $\begin{array}{l}\text { Christopher and Towill } \\
(2000)\end{array}$ & quality, cost, lead-time, and service level \\
\hline $\begin{array}{l}\text { Agarwal and Shankar } \\
(2002)\end{array}$ & Lead time, cost and service level \\
\hline Stewart (1995) & $\begin{array}{l}\text { Delivery performance, flexibility and responsiveness, logistics cost, and } \\
\text { asset management }\end{array}$ \\
\hline Gilmor (1999) & $\begin{array}{l}\text { customer relationship, customer segmentation, order taking process, order } \\
\text { tracking system and customer satisfaction }\end{array}$ \\
\hline $\begin{array}{l}\text { Gunasekeran et al. (2001) } \\
\text { pg. } 83\end{array}$ & $\begin{array}{l}\text { Operationalize SCM performance at three different levels: } \\
\text { some items are as follows: 1) Strategic: Customer query time Level of } \\
\text { customer perceived value of product ,Order lead time, Flexibility of } \\
\text { service systems; 2) Tactical: Product development cycle time, Purchase } \\
\text { order cycle time, Planned process cycle time, Delivery reliability, } \\
\text { Responsiveness to urgent deliveries, Effectiveness of distribution } \\
\text { planning; 3) Operational: Capacity utilization, Total inventory as: } \\
\text { Incoming stock level, Work-in-progress } \pm \text { Scrap level, } \pm \text { Finished goods } \\
\text { in transit }\end{array}$ \\
\hline Morgan (2004) & Cost performance, customer service, quality, operational productivity \\
\hline
\end{tabular}




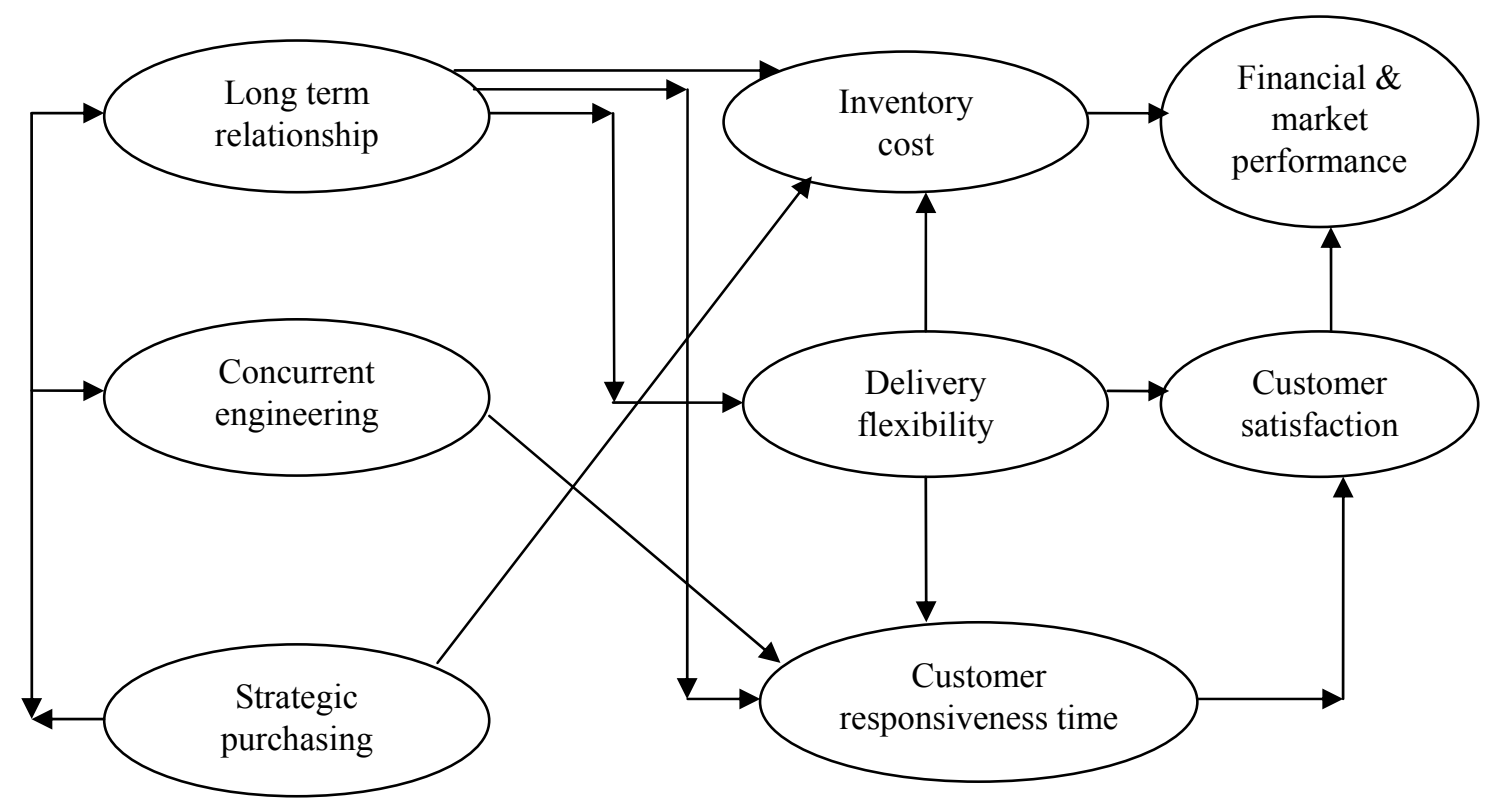

Figure 1. An Integrated Framework for SCM Dimensions, SCM performance and Organization Performance 